\title{
Species richness and community structure of class Polyplacophora at the intertidal rocky shore on the marine priority region no. 33, Mexico
}

\author{
Lizeth Galeana-Rebolledo ${ }^{1 *}$, Rafael Flores-Garza ${ }^{1}$, Adriana Reyes-Gómez $^{1}$, \\ Sergio García-Ibáñez ${ }^{1}$, Pedro Flores-Rodríguez ${ }^{1}$, Carmina Torreblanca-Ramírez ${ }^{1}$, \\ Arcadio Valdés-González ${ }^{2}$ \\ ${ }^{1}$ Unidad Académica de Ecología Marina, Universidad Autónoma de Guerrero, Acapulco, México; \\ *Corresponding Author: lizeth_galeana@yahoo.com.mx \\ ${ }^{2}$ Universidad Autónoma de Nuevo León, Laboratorio de Acuacultura, Facultad de Ciencias Biológicas, Ciudad Universitaria, San \\ Nicolás de los Garza, México
}

Received 4 December 2013; revised 3 January 2014; accepted 10 January 2014

Copyright (C) 2014 Lizeth Galeana-Rebolledo et al. This is an open access article distributed under the Creative Commons Attribution License, which permits unrestricted use, distribution, and reproduction in any medium, provided the original work is properly cited. In accordance of the Creative Commons Attribution License all Copyrights (C) 2014 are reserved for SCIRP and the owner of the intellectual property Lizeth Galeana-Rebolledo et al. All Copyright (C) 2014 are guarded by law and by SCIRP as a guardian.

\section{ABSTRACT}

Marine Priority Region No. 33 (MPR 33) lies in the State of Guerrero, where the National Commission for Knowledge and Use of Biodiversity has declared a lack of information on marine species, Class POLYPLACOPHORA among others. This program was carried out on the rocky intertidal zone of MPR 33 with the objectives to: 1) determine species richness, 2) community composition based on families represented, 3) estimate the density, 4) index of diversity, 5) analyze body proportions and 6) geographic distribution of species. Three surveys on five sites were conducted during 2009 and 2012, using one $\mathrm{mt}^{2}$ quadrant for systematic sampling procedure; collecting all POLYPLACOPHORA specimens found within the quadrants, then proceeding with their preservation. 441 organisms were analyzed where 17 species were identified, on nine genera within six families. Fifteen new species were recorded for the MPR 33. Family ISCHNOCHITONIDAE Dall, 1889 was the best represented in species richness and $\mathrm{CHI}-$ TONIDAE Rafinesque, 1815 in abundance. Density of 8.82 organisms $/ \mathrm{m}^{2}$, the $\mathrm{H}^{\prime}$ index was 2.38 bits/individuals and $\mathrm{J}^{\prime}=\mathbf{0 . 5 7}$. The species Chiton (Chiton) articulatus Sowerby, 1832 showed the highest density, greater size and was found in all five collection sites. Three species, (Chiton (C.) articulatus, Ischnochiton (Ischnochiton) muscarius (Reeve, 1847) and Chiton (Chiton) alboli- neatus Broderip \& Sowerby, 1829), were considered wide. Intertidal species richness was associated with habitat stability and wave intensity; the more unstable sites had greater richness while most stable sites lower. Species inventory and understanding the communities' interactions of the marine fauna of the State of Guerrero are important; therefore these efforts must be continued.

\section{KEYWORDS}

Polyplacophora; New Records; Methodology; RMP 33; Guerrero

\section{INTRODUCTION}

Mexico has seven marine ecoregions of the 24 existing ones in the North American Continent. The Pacific Region 17, also called Pacific Mexican Transitional, includes the coastal waters of the Mexican states of Jalisco, Colima, Michoacán, Guerrero, Oaxaca, and the southernmost tip of Baja California Sur. This physiographic region is characterized by narrow continental shelf with width amplitude of 10 - $15 \mathrm{~km}$ and a slope of less than $1^{\circ} 30^{\prime}$ with a deep oceanic trench, and complex abyssal plains [1]. For the State of Guerrero, the National Commission for the Knowledge and Use of Biodiversity Comision Nacional Para el Uso y Conocimiento de la Biodiversidad (CONABIO) stated that there are four marine priority areas for the conservation of coastal and 
ocean biodiversity; about these regions, CONABIO has highlighted the lack of knowledge about the diversity of marine species [2], hence it is necessary to conduct research to gain information on the species diversity and analyze the ecological aspects of populations and communities. This research was carried out on the rocky intertidal zone of the State of Guerrero, Marine Priority Region No. 33 (MPR 33) Copala-Punta Maldonado. Besides the lack of knowledge of its biodiversity, CONABIO also notes that it presents severe garbage pollution problems from sewage and agricultural runoff, and a strong impact from tourist activities in the region, declaring this area as high priority because of its wide variety of habitats and the need to protect their species. Among other organisms found in MPR 33, is the class POLYPLACOPHORA or Chitons as they are commonly known. These are primitive mollusks with oval shaped shells consisting of eight joined, articulated segments. These segments are surrounded by a sort of wide belt, with a broad muscular foot which emphasizes a small head with the mouth opening toward the front, and at the opposite end of the muscle foot, is the anus; they inhabit rock masses and/or loose rocks, adjusting their anatomy to them [3]. Despite their diversity and abundance, they are usually underestimated in faunal studies, probably due to the fact that they are not considered to be a species of commercial value and the little information we have for this type of organism, probably comes from the cryptic habitats where most species live, and the difficulties it presents in obtaining access to the area in which they are found in greater abundance [4]. There are global reports concerning Class POLYPLACOPHORA on a taxonomic scope and geographical distribution such as [5-8] for the American Pacific as $[9,10]$, as well as those made in the Mexican coast zone as [3,4,11-13]; other studies also found Chitons' ecological data as [14-16]. With respect to marine priority coastal regions in the State of Guerrero, [17] reported for Marine Priority Region No. 32. Moreover, most of the reports with information about the class POLYPLACOPHORA for the State of Guerrero were made on the basis of mollusk communities where Chitons are part of the analyzed classes, among those reports are [18-28], which analyzed the rocky intertidal mollusks in some areas of the MPR 32 and 33, providing information on existing POLYPLACOPHORA in these habitats.

This research was conducted in order to deepen the understanding of the class POLYPLACOPHORA on the rocky intertidal MPR 33, the objectives were: 1) to determine species richness, 2) composition of the community based on the most represented families, 3) estimate the density, 4) and diversity index, 5) analyze species length-width structure and 6) the geographic distribution of species.

\section{FIELD METHODOLOGY}

\subsection{Study Area}

The Marine Priority Region No. 33 Copala-Punta Maldonado, is set between the states of Guerrero and Oaxaca, with an area of $6352 \mathrm{~km}^{2}$, it is located at latitude $16^{\circ} 32$ '24" to $15^{\circ} 36^{\prime}$ and longitude $99^{\circ} 24^{\prime} 36^{\prime \prime}$ to $98^{\circ} 12^{\prime}$. The climate is sub-humid, with tropical storms and hurricanes. It belongs to the North American plate, formed by igneous, sedimentary and metamorphic rocks, and has a narrow platform. Current predominant waterfront is North equatorial from Costa Rica and presents high, medium, and low, waves occurring red tide, "El Niño" and turbulence processes, and receives freshwater input from rivers, lakes and estuaries [2].

Five sites were sampled on the rocky intertidal zone at the MPR 33, each location was geographically referenced and described according to the following criteria: type of substrate, types of rock, substrate stability and wave exposure. The descriptions of the collecting sites were based on [2] and produced by the National Institute of Statistics, Geography and Informatics (INEGI Instituto Nacional de Geografia, Estadistica e Informatica) and were complemented with field observations (Table 1). These sites vary in type, substrate stability and wave exposure. Substrate types were classified as: 1) Massif rocks: fixed structures such as walls, cliffs, terraces, etc., 2) Blocks: loose rock larger than $50 \mathrm{~cm}$ in diameter, made of rocks submerged and immovable or that are difficult to move about by the impact of waves, 3) Boulders: loose rock of size less than 50 and greater than $8 \mathrm{~cm}$ in diameter, rocks that can be easily moved by the impact of waves., 4) Gravel: loose rock no more than 8 $\mathrm{cm}$ in diameter. The stability of the substrate was classified as: 1) High: when the substrate remains virtually unchanged by the impact of waves, 2) Middle: when the impact of the waves does not change the configuration of the substrate but there is rock movement, 3) Low: when the site configuration changes by the impact of waves, most of the rocks are moved. The wave exposure was classified as: 1) High: when the wave hits the substrate in a free manner, usually the sites that have this type of waves are outside from the protection of barriers such as bays or hooks, 2) Middle: when the impact of the wave on the substrate is hindered by barriers or smoothing, as can occur at sites that are in front of the entrance of bays or at a distance from a wall of hooks, it also happens in places where subtidal rocky substrate merges or is shallow and reduces the direct impact of the waves to the substrate, 3) Low: when the wave does not directly hit the substrate, since the sites are protected by different types of barriers.

\subsection{Fieldwork}

Three samples were conducted per site between 2009 
Table 1. Geographical location of sampling sites and the major characteristics of the rocky intertidal habitat on the Marine Priority Region No. 33, Mexico.

\begin{tabular}{|c|c|c|c|c|c|c|c|c|}
\hline & \multirow{2}{*}{ Sites } & \multicolumn{2}{|c|}{ Coordinates } & \multirow{2}{*}{ Municipality } & \multirow{2}{*}{$\begin{array}{l}\text { Type of } \\
\text { Substrate }\end{array}$} & \multirow{2}{*}{$\begin{array}{l}\text { Type of } \\
\text { Rock }\end{array}$} & \multirow{2}{*}{$\begin{array}{l}\text { Substrate } \\
\text { stability }\end{array}$} & \multirow{2}{*}{$\begin{array}{l}\text { Wave } \\
\text { exposure }\end{array}$} \\
\hline & & Latitude & Longitude & & & & & \\
\hline 1 & Playa Ventura & $16^{\circ} 32^{\prime} 8.3^{\prime \prime}$ & $99^{\circ} 54^{\prime} 44.6^{\prime \prime}$ & Copala & Massif rocks & Igneous & High & High \\
\hline 2 & Casa de Piedra & $16^{\circ} 32^{\prime} 10.15^{\prime \prime}$ & $98^{\circ} 53^{\prime} 47.35^{\prime \prime}$ & Copala & Massif rocks & Igneous & High & High \\
\hline 3 & Las Salinas & $16^{\circ} 35^{\prime} 49.56^{\prime \prime}$ & $99^{\circ} 05^{\prime} 43.71^{\prime \prime}$ & Marquelia & Massif rocks & Igneous & High & High \\
\hline 4 & Peñitas & $16^{\circ} 33^{\prime} 14.4^{\prime \prime}$ & $98^{\circ} 46^{\prime} 22.0^{\prime \prime}$ & Marquelia & Massif rocks & Metamorphic & High & High \\
\hline 5 & Punta Maldonado & $16^{\circ} 19^{\prime} 35.49^{\prime \prime}$ & $98^{\circ} 34^{\prime} 12.65^{\prime \prime}$ & Cuajinicuilapa & $\begin{array}{l}\text { Blocks and } \\
\text { Boulders }\end{array}$ & $\begin{array}{l}\text { Sedimentary sand } \\
\text { stone }\end{array}$ & Middle & Middle \\
\hline
\end{tabular}

and 2012. Sampling was performed during the hours of low tide at new moon days.

To carry on the quantification of organisms an area of $10 \mathrm{~m}^{2}$ was sampled per site. Sampling was systematic. The starting point was randomly selected and then a nylon rope $30 \mathrm{~m}$ long was placed parallel to the shore on the intertidal zone using a PVC pipe square frame $1 \mathrm{~m}$ per side to delimit the sampling unit. Once the starting point was established, the PVC frame was placed at the selected point. All POLYPLACOPHORA specimens found alive, even those attached under rocks within the sampling unit, were collected and placed into a plastic container filled with seawater and protected from direct sunlight. After completing the collection, a $2 \mathrm{~m}$ intersection along the rope was measured then the frame was again replaced the frame again to define the following sampling unit. This procedure was repeated ten times along the nylon rope. Upon sample completion, specimens' preservation consisted of placing living ones between two pieces of wood, one on the ventral side and the other on the back, fastening with rubber bands to exert slight pressure and preventing them from bending. The specimens between the pieces of fixed wood were placed in labeled jars containing 96\% ethyl alcohol. They were then taken to the laboratory to be identified, quantified and measured. The sites are protected by different types of barriers.

\subsection{Laboratory Work and Data Analysis}

Species identification was done using specialized literature such as [5-8,30]. The systematic classification was based on POLYPLACOPHORA by [31]. The specimens collected and identified were counted, the length and width in millimeters ( $\mathrm{mm}$ ) was measured.

Richness was based on the number of species found in the samples. The community composition was analyzed using the representation of families, which was evaluated based on species richness and abundance of organisms per family and expressed as percentage. Density was measured by estimating the average amount of specimens $/ \mathrm{m}^{2}$. The analysis of structure of POLYPLACOPHORA populations was considered by measuring the length and width, and obtained the statistical descriptive values such as maximum, minimum, mean and standard deviation expressed in millimeters was obtained using a digital Vernier type caliper (accuracy $0.01 \mathrm{~mm}$ ). The diversity was measured using the Shannon-Wiener $\left(\mathrm{H}^{\prime}\right)$ index and the evenness index of Pielou $\left(J^{\prime}\right)$ or equity.

To analyze the distribution of Polyplacophora species in the MPR 33 the percentage of sites at which the species was present (frequency of occurrence) was used as a criterion and classified as follows: 1) broad distribution: when the species appeared in at least $80 \%$ of the sites, 2) regular distribution: when the species was collected in $60 \%$ of the sites; 3) limited distribution: when the species is found in $40 \%$ of sites, and 4 ) irregular distribution: when the species was found in $20 \%$ of the sites or less.

\section{RESULTS}

441 specimens for the class POLYPLACOPHORA from the MPR 33 were analyzed; we identified 17 species for nine genera and six families. Fifteen species were found as new record (Figure 1). The best represented families in terms of species richness were ISCHNOCHITONIDAE with three genera and five species, followed by TONICELLIDAE Simroth, 1894 one genus and five species. CHITONIDAE was the better represented family in abundance by $45.80 \%$ of the total specimens analyzed and the less abundant ACANTHOCHITONIDAE Pilsbry, 1893 with $0.22 \%$ (Table 2).

A density of 8.82 specimens $/ \mathrm{m}^{2}$ was found. Chiton (Chiton) articulatus, showed the highest density, followed by Lepidochitona sp. 2. Punta Maldonado was the site that had the highest density, which was 22 specimens $/ \mathrm{m}^{2}$ and the lowest density was found in Playa Ventura being 1.3 specimens $/ \mathrm{m}^{2}$ (Table 3).

The value of Shannon-Wiener diversity index (H') calculated for Marine Priority Region No. 33 was 2.38 bits/individual, while the value of equity index and Pielou evenness $\left(J^{\prime}\right)$ was 0.57 . The site that showed the highest indexes values was Playa Ventura, which were H' $=1.83 \mathrm{bits} /$ individuals and $\mathrm{J}^{\prime}=0.79$; while Peñitas showed the lowest values of $\mathrm{H}^{\prime}$ and $\mathrm{J}$ ' $=0.66$ (Table 3 ).

On body size proportions, Chiton. (C) articulatus showed the greatest length, $45.75 \mathrm{~mm}$ (minimum $=7.88$ 


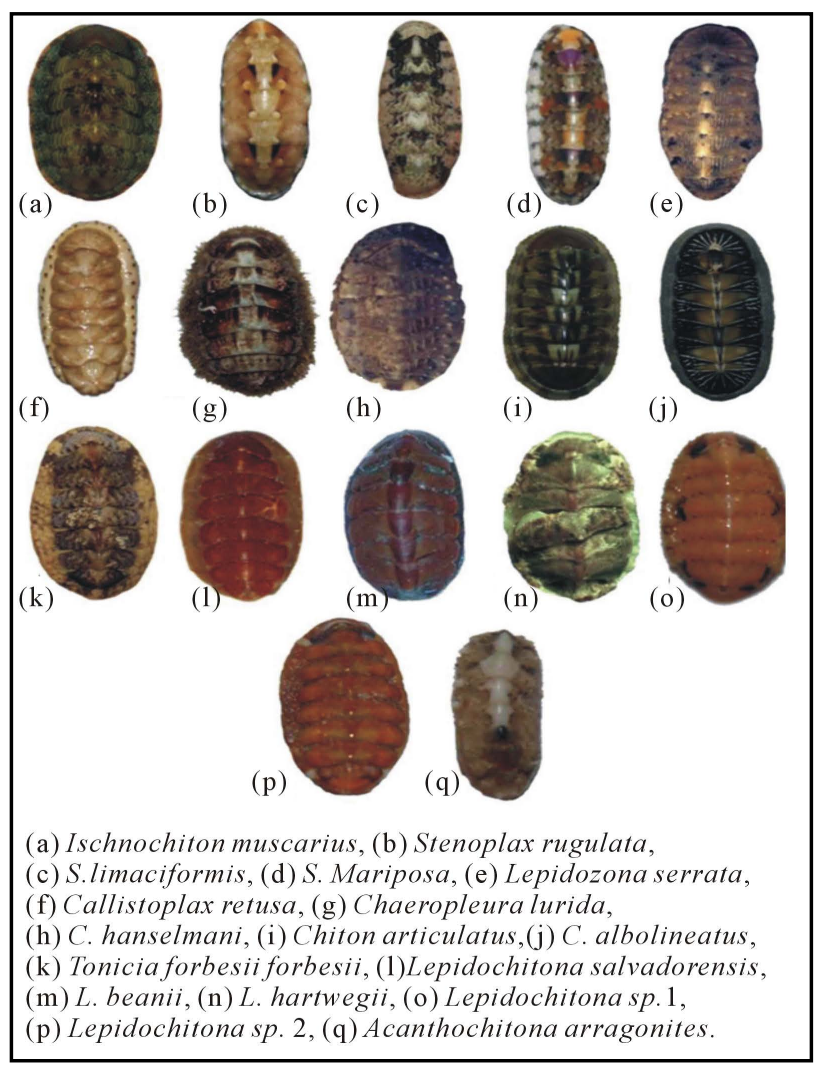

Figure 1. Species of Class Polyplacophora at the rocky intertidal zone on the Marine Priority Region No. 33, Mexico.

$\mathrm{mm}$, mean $=18.39 \mathrm{~mm}$ and standard deviation $=9.52$ ) and Ischnochiton (I.) muscarius presented the smallest size with $2.21 \mathrm{~mm}$ (maximum $=13 \mathrm{~mm}$, mean $=7.08$ $\mathrm{mm}$ and standard deviation: 2.52). Regarding to width Chiton (C.) articulatus showed the greatest size in width, 22.99 (minimum $=3.36 \mathrm{~mm}$, mean $=15.85 \mathrm{~mm}$, and standard deviation $=4.50$ ) and Stenoplax (Stenoplax) mariposa (Barsch MS, Dall, 1919) showed the smallest size $1.73 \mathrm{~mm}$ (maximum $=4.40 \mathrm{~mm}$, mean $=2.70$ and standard deviation $=0.84)$ (Table 4$)$.

Regarding the geographical distribution in MPR 33, Chiton (C.) articulatus was located in the five collection sites while Stenoplax (Stenoplax) limaciformis (Sowerby, 1832) was found in four of the five sites, these species were reported as widely distributed, plus two species found with regular distribution, nine irregular and four had limited distribution (Table 5 and Figure 2).

\section{DISCUSSION AND CONCLUSION}

\subsection{Species Richness}

Species richness reports made by [3,4,9-13] for the Mexican Pacific where chitons are discussed, are all in agreement to what has been found' in the MRP 33 for the following species: Ischnochiton (I.) muscarius, Stenoplax (S.) limaciformis, Stenoplax (S.) butterfly, Stenoplax
(S.) rugulata, Lepidozona (L.) serrata, Callistoplax retusa, Chaetopleura (C.) lurida, Chaetopleura (C.) hanselmani, Tonicia (T.) forbesii forbesii, Chiton (C.) albolineatus, Chiton (C.) articulatus, Lepidochitona (L.) salvadorensis, Lepidochitona (L.) beanii, Lepidochitona sp. and Acanthochitona arragonites. With respect to species richness reported for different sites of the Marine Region Priority No. 32, also located in the state of Guerrero, which analyzed the Class POLYPLACOPHORA, among other classes of mollusks, are those of [18,20,23-25,27,28], their numbers of POLYPLACOPHORA species was less than what is reported for this study. However, [17] in a paper which discusses only the class POLYPLACOPHORA in MPR 32 reported 20 species of Chitons, three more than in this report. The species that were not found in the MPR 33 were: Callistochiton elenensis, Chaetopleura (C.) unilineata and Lepidochitona (D.) flectens. The absence of these species might because the substrate, in the MPR 33 is less varied in structure, wave exposure and stability. In this regard, [33] noted that beaches composed of large boulders are physically more stable than beaches composed of small or loose rocks, so it points to a direct correlation of this type of beaches between habitat stability and species richness. [34] on Costa Rica, found that their site substrate consisted of small rounded smooth stones, might have caused a wealth of [32] species against [25] with firm substrate at a cliff type site; and [26], observed that the highest species richness of intertidal mollusks in the State of Guerrero, was associated with habitat stability and wave intensity at each site, so that more unstable sites, which are those whose substrate consists of boulders and a lower wave intensity, showed greater species richness than stable sites in the substrate formed by large blocks with few cracks and crevices and high wave intensity. $[22,26]$ reported Chiton (C.) articulatus and Chiton (C.) albolineatus as fauna of Chitons on three sites of MPR 33. This research found that [15] species had not been recorded

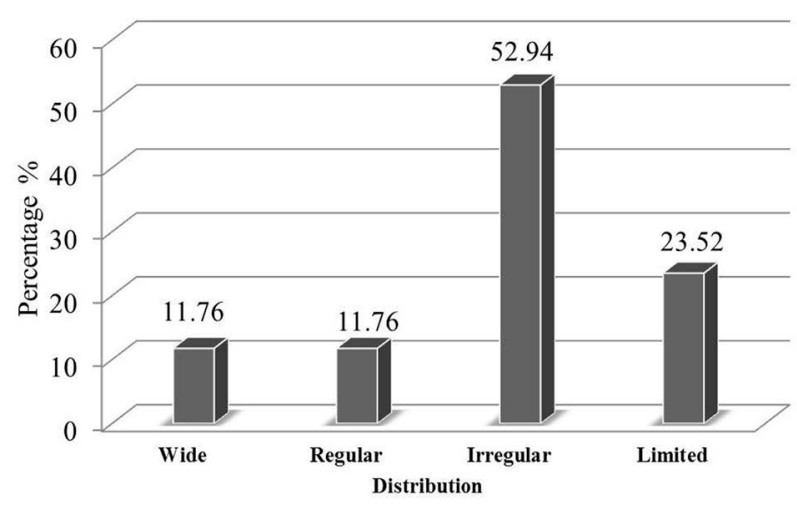

Figure 2. Distributional type for class POLYPLACOPHORA by frequency of occurrence of the species on the rocky intertidal at the Marine Priority Region No. 33, Mexico. 
Table 2. Species richness, relative abundance, density specimens $/ \mathrm{m}^{2}$, and $\left(^{*}\right)$ new records for Class POLYPLACOPHORA at the rocky intertidal Marine Priority Region No. 33, Mexico.

\begin{tabular}{|c|c|c|}
\hline Family/species & Relative Abundance by family & Density \\
\hline \multicolumn{3}{|l|}{ Ischnochitonidae Dall, 1889} \\
\hline "Ischnochiton (Ischnochiton) muscarius (Reeve, 1847) & \multirow{5}{*}{$21.0 \%$} & 1.42 \\
\hline *Stenoplax (Stenoplax) rugulata (Sowerby, 1832) & & 0.14 \\
\hline "Stenoplax (Stenoplax) limaciformis (Sowerby,1832) & & 0.26 \\
\hline "Stenoplax (Stenoplax) mariposa (Barsch MS, Dall, 1919) & & 0.04 \\
\hline${ }^{*}$ Lepidozona (Lepidozona) serrata (Carpenter, 1864) & & 0.02 \\
\hline \multicolumn{3}{|l|}{ Callistoplacidae Pilsbry, 1893} \\
\hline${ }^{*}$ Callistoplax retusa (Sowerby in Broderip \& Sowerby, 1832) & $0.45 \%$ & 0.04 \\
\hline \multicolumn{3}{|l|}{ Chaetopleuridae Plate, 1899} \\
\hline *Chaetopleura (Chaetopleura) lurida (Sowerby in Broderip \& Sowerby, 1832) & \multirow{2}{*}{$10.88 \%$} & 0.92 \\
\hline "Chaetopleura (Chaetopleura) hanselmani (Ferreira, 1982) & & 0.04 \\
\hline \multicolumn{3}{|l|}{ Chitonidae Rafinesque, 1815} \\
\hline Chiton (Chiton) articulatus Sowerby, 1832 & & 3.02 \\
\hline Chiton (Chiton) albolineatus Broderip \& Sowerby, 1829 & $45.80 \%$ & 1 \\
\hline "Tonicia (Tonicia) forbesii forbesii Carpenter, 1857 & & 0.02 \\
\hline \multicolumn{3}{|l|}{ Tonicellidae Simroth, 1894} \\
\hline "Lepidochitona (Lepidochitona) salvadorensis (García-Ríos, 2006) & & 0.06 \\
\hline "Lepidochitona (Lepidochitona) beanii Carpenter, 1857 & & 0.1 \\
\hline "Lepidochitona (Lepidochitona) hartwegii (Carpenter, 1855) & $21.31 \%$ & 0.04 \\
\hline${ }^{*}$ Lepidochitona sp. 1 & & 0.16 \\
\hline${ }^{*}$ Lepidochitona sp. 2 & & 1.52 \\
\hline \multicolumn{3}{|l|}{ Acanthochitonidae Pilsbry, 1893} \\
\hline "Acanthochitona arragonites (Carpenter, 1847) & $0.22 \%$ & 0.02 \\
\hline
\end{tabular}

Table 3. Density (specimens $/ \mathrm{m}^{2}$ ) and diversity index for Class POLYPLACOPHORA at the rocky intertidal Marine Priority Region No. 33, in the State of Guerrero, Mexico.

\begin{tabular}{|c|c|c|c|}
\hline \multirow{2}{*}{ Sites } & \multirow{2}{*}{ Density } & \multicolumn{2}{|c|}{ Diversity Índex (bits/individual) } \\
\hline & & $\mathrm{H}^{\prime}$ & $\mathrm{J}^{\prime}$ \\
\hline Playa Ventura & 1.3 & 1.83 & 0.79 \\
\hline Casa de Piedra & 4.8 & 1.29 & 0.64 \\
\hline Las Salinas & 9.4 & 1.79 & 0.54 \\
\hline Peñitas & 6.6 & 1.05 & 0.66 \\
\hline Punta Maldonado & 22 & 2.29 & 0.58 \\
\hline General & 8.82 & 2.38 & 0.57 \\
\hline
\end{tabular}

for this region. The difference between the number of species reported earlier for this region and those found in this research, could be due to the methodology for collecting, since this was designed specifically for POLYPLACOPHORA collection and the sampling units were carefully managed and reviewed, and the amount of sampled sites was higher and representative of different types of rock substrates on the MPR 33.

Table 6 presents the species list of new records for the rocky intertidal Marine Priority Region No. 33. One of the reasons to have a complete knowledge of the distribution is that it allows the precise determination of suitable habitat for each of the species. Knowing the habitat requirements for a species and the availability of these types of habitats in a region, we may assume the population status of the species in the spatial and temporal context [36]. It is consistent with [35] on that if we know the habitat requirements of the species distribution, facilitates the identification of priority areas for conservation. Moreover, the inventory can provide further arguments to justify the conservation of important areas.

\subsection{Community Composition}

Based on the representation of families as reported by [18-21] has identified CHITONIDAE as the family best represented in number of species and abundance. Regarding species richness [24,27] reported ISCHNO 
Table 4. Size measurements of POLYPLACOPHORA species found at the intertidal rocky shores of Marine Priority Region No. 33, Mexico.

\begin{tabular}{|c|c|c|c|c|c|c|c|c|}
\hline \multirow{2}{*}{ Species } & \multicolumn{4}{|c|}{ Long (mm) } & \multicolumn{4}{|c|}{ Width (mm) } \\
\hline & Minimum & Maximum & Mean & Standard Deviation & Minimum & Maximum & Mean & Standard Deviation \\
\hline Ischnochiton (I.) muscarius & 2.21 & 13 & 7.08 & 2.52 & 1.84 & 8.98 & 4.52 & 1.47 \\
\hline Stenoplax $(S$.$) rugulata$ & 4.73 & 9.61 & 7.61 & 2.55 & 2.39 & 3.38 & 2.88 & 0.70 \\
\hline Stenoplax (S.) limaciformis & 5.33 & 29.54 & 17.08 & 6.18 & 2.69 & 5.74 & 4.54 & 0.91 \\
\hline Stenoplax (S.) mariposa & 6.41 & 8.45 & 7.43 & 1.44 & 1.73 & 4.40 & 2.70 & 0.84 \\
\hline Lepidozona (L.) serrata & 8.23 & 8.23 & 8.23 & - & 3.93 & 3.93 & 3.93 & - \\
\hline Callistoplax retusa & 5.04 & 24.07 & 14.01 & 4.9 & 3.34 & 5.71 & 4.51 & 1.33 \\
\hline Chaetopleura (C.) lurida & 5.11 & 30.97 & 17.90 & 4.52 & 5.55 & 15.70 & 10.99 & 2.38 \\
\hline Chaetopleura (C.) hanselmani & 3.17 & 4.35 & 3.76 & 0.83 & 3.99 & 4.26 & 4.13 & 0.19 \\
\hline Chiton (C.) articulatus & 7.88 & 45.75 & 18.39 & 9.52 & 3.36 & 22.99 & 15.85 & 4.50 \\
\hline Tonicia (T.) forbesii forbesii & 31.84 & 31.84 & 31.84 & - & 19.35 & 19.35 & 19.35 & - \\
\hline Lepidochitona (L.) salvadorensis & 6.01 & 13.77 & 9.39 & 2.65 & 3.03 & 5.25 & 4.14 & 1.57 \\
\hline Lepidochitona (L.) beanii & 6.12 & 6.28 & 6.2 & 0.11 & 3.01 & 3.77 & 3.39 & 0.54 \\
\hline Lepidochitona (L.) hartwegii & 4.27 & 5.1 & 4.68 & 0.58 & 4.27 & 5.10 & 4.69 & 0.59 \\
\hline Lepidochitona sp. 1 & 7.8 & 24.07 & 14.44 & 4.34 & 2.79 & 5.53 & 4.07 & 1.00 \\
\hline Lepidochitona sp. 2 & 4.21 & 8.46 & 5.744 & 1.71 & 2.51 & 4.72 & 3.86 & 0.55 \\
\hline Acanthochitona arragonites & 8.37 & 8.37 & 8.37 & - & 6.12 & 6.12 & 6.12 & - \\
\hline
\end{tabular}

Table 5. Type of geographical distribution of the POLYPLACOPHORA Class species on the rocky intertidal Marine Region Priority No. 33, Mexico.

\begin{tabular}{|c|c|c|c|c|c|c|}
\hline Species & 1 & 2 & 3 & 4 & 5 & Distribution \\
\hline Ischnochiton (I.) muscarius & $\mathrm{X}$ & & $\mathrm{X}$ & & $\mathrm{X}$ & Regular \\
\hline Stenoplax $(S$.$) rugulata$ & & & & & $\mathrm{X}$ & Irregular \\
\hline Stenoplax (S.) limaciformis & $\mathrm{X}$ & $\mathrm{X}$ & $\mathrm{X}$ & & $\mathrm{X}$ & Wide \\
\hline Stenoplax (S.) mariposa & & & & & $\mathrm{X}$ & Irregular \\
\hline Lepidozona (L.) serrata & & & & & $\mathrm{X}$ & Irregular \\
\hline Callistoplax retusa & & & & & $\mathrm{X}$ & Irregular \\
\hline Chaetopleura (C.) lurida & & & & $\mathrm{X}$ & $\mathrm{X}$ & Limited \\
\hline Chaetopleura (C.) hanselmani & & & & & $\mathrm{X}$ & Irregular \\
\hline Chiton (C.) articulatus & $\mathrm{X}$ & $\mathrm{X}$ & $\mathrm{X}$ & $X$ & $\mathrm{X}$ & Wide \\
\hline Chiton (C.) albolineatus & & & & & $\mathrm{X}$ & Irregular \\
\hline Lepidochitona (L.) salvadorensis & & & $\mathrm{X}$ & & $\mathrm{X}$ & Limited \\
\hline Lepidochitona (L.) beanii & & & $\mathrm{X}$ & & $\mathrm{X}$ & Limited \\
\hline Lepidochitona (L.) hartwegii & $\mathrm{X}$ & & $\mathrm{X}$ & & $\mathrm{X}$ & Regular \\
\hline Lepidochitona sp. 1 & & $\mathrm{X}$ & $\mathrm{X}$ & & & Limited \\
\hline Lepidochitona sp. 2 & & & $\mathrm{X}$ & & & Irregular \\
\hline Acanthochitona arragonites & & & $\mathrm{X}$ & & & Irregular \\
\hline
\end{tabular}

1 = Playa Ventura, 2 = Casa de Piedra, 3 = Las Salinas, 4 = Peñitas, 5 = Punta Maldonado.

CHITONIDAE as the best represented family while $[17,25]$ reported the family TONICELLIDAE as the bester presented species. The present investigation reports to
ISCHNOCHITONIDAE in species richness and abundance, CHITONIDAE as the most representative for Marine Priority Region. 
Table 6. Known species distribution and new records distribution on Class POLYPLACOPHORA of the rocky intertidal zone of Marine Priority Region No. 33, Mexico.

\begin{tabular}{|c|c|c|c|}
\hline Species & $\begin{array}{l}\text { Number of } \\
\text { specimens }\end{array}$ & Known distribution & New distribution \\
\hline $\begin{array}{l}\text { Ischnochiton } \\
\text { (I.) muscarius }\end{array}$ & 71 items & $\begin{array}{l}\text { West Coast of Mexico, Mexican Tropical Pacific (Gulf of California, } \\
\text { Sonora Venado Island, in La Ventosa Oaxaca, State of Guerrero in the } \\
\text { MPR No. } 32 \text { and Zihuatanejo, Revillagigedo Archipelago and Isla Socorro). } \\
\text { [5,10,12,14,18-20,25-29] }\end{array}$ & $\begin{array}{l}\text { Playa Ventura } 16^{\circ} 32^{\prime} 8.3^{\prime \prime} 99^{\circ} 54^{\prime} 44.6^{\prime \prime} \\
\text { Salinas } 16^{\circ} 35^{\prime} 49.56^{\prime \prime} 99^{\circ} 05^{\prime} 43.71^{\prime \prime} \\
\text { Punta Maldonado } 16^{\circ} 19^{\prime} 35.49^{\prime \prime} \\
98^{\circ} 34^{\prime} 12.65^{\prime \prime}\end{array}$ \\
\hline $\begin{array}{l}\text { Stenoplax }(S .) \\
\quad \text { rugulata }\end{array}$ & 7 items & $\begin{array}{c}\text { México; (Gulf of California and the state of Guerrero on the MPR No. 32), } \\
\text { Ecuador (Galapagos Islands), Perú, Nicaragua, Costa Rica, Panamá } \\
\text { and Western Atlantic. [5,10,11,13,18,26,29] }\end{array}$ & $\begin{array}{l}\text { Punta Maldonado } 16^{\circ} 19^{\prime} 35.49^{\prime \prime} \\
98^{\circ} 34^{\prime} 12.65^{\prime \prime}\end{array}$ \\
\hline $\begin{array}{l}\text { Stenoplax }(S .) \\
\text { limaciformis }\end{array}$ & 13 items & $\begin{array}{l}\text { México; (Gulf of California, State of Guerrero in the MPR No. 32, } \\
\text { in Puerto Angelito, Puerto Escondido, Estacahuite, Oaxaca) to Perú } \\
\text { (Islas Lobos Outside), Ecuador (Punta Ancon) and the Caribbean. } \\
{[4,5,10-14,18,19,25,26,28,29]}\end{array}$ & $\begin{array}{c}\text { Playa Ventura } 16^{\circ} 32^{\prime} 8.3^{\prime \prime} 99^{\circ} 54^{\prime} 44.6^{\prime \prime} \text {, } \\
\text { Casa de Piedra } 16^{\circ} 32^{\prime} 10.15^{\prime \prime} \\
98^{\circ} 53^{\prime} 47.35^{\prime \prime} \text {, Salinas } 16^{\circ} 35^{\prime} 49.56^{\prime \prime} \\
99^{\circ} 05^{\prime} 43.71^{\prime \prime}, \\
\text { Punta Maldonado } 16^{\circ} 19^{\prime} 35.49^{\prime \prime} \\
98^{\circ} 34^{\prime} 12.65^{\prime \prime}\end{array}$ \\
\hline $\begin{array}{l}\text { Stenoplax }(S .) \\
\quad \text { mariposa }\end{array}$ & 2 items & $\begin{array}{l}\text { México; (Golfo de California, Estado de Guerrero en la MPR No. 32, } \\
\text { Oaxaca en Puerto Angelito, Puerto Escondido, Estacahuite), Perú } \\
\text { (Islas Lobos Afuera), Ecuador (Punta Ancón) y en el Caribe. } \\
{[4,7,10-14,18,37,38]}\end{array}$ & $\begin{array}{l}\text { Punta Maldonado } 16^{\circ} 19^{\prime} 35.49^{\prime \prime} \\
98^{\circ} 34^{\prime} 12.65^{\prime \prime}\end{array}$ \\
\hline $\begin{array}{l}\text { Lepidozona }(L .) \\
\text { serrata }\end{array}$ & 1 item & $\begin{array}{l}\text { México; (Gulf of California, south of Mazatlán, Sinaloa and to Kino Bay, } \\
\text { Sonora, State of Guerrero in the MPR No. } 32 \text { and Chachacual-Jicaral, } \\
\text { Huatulco in Oaxaca, Nayarit Marias Islands). } \\
{[44,5,10-14,18,26,28,29,37]}\end{array}$ & $\begin{array}{l}\text { Punta Maldonado } 16^{\circ} 19^{\prime} 35.49^{\prime \prime} \\
98^{\circ} 34^{\prime} 12.65^{\prime \prime}\end{array}$ \\
\hline $\begin{array}{l}\text { Callistoplax } \\
\text { (C.) retusa }\end{array}$ & 2 items & $\begin{array}{l}\text { México, (State of Guerrero in the MPR No. } 32 \text { and Zihuatanejo, } \\
\text { Chachacual-Jicaral Estacahuite Huatulco and Oaxaca, Nayarit Marías Islands) } \\
\text { and Panamá.[4,8,10,11,12,14,18-20,25,26,28,29] }\end{array}$ & $\begin{array}{l}\text { Peñitas } 16^{\circ} 33^{\prime} 14.4^{\prime \prime} 98^{\circ} 46^{\prime} 22.0^{\prime \prime} \\
\text { Punta Maldonado } 16^{\circ} 19^{\prime} 35.49^{\prime \prime} \\
98^{\circ} 34^{\prime} 12.65^{\prime \prime}\end{array}$ \\
\hline $\begin{array}{l}\text { Chaetopleura } \\
\text { (C.) lurida }\end{array}$ & 46 items & $\begin{array}{l}\text { México; (Gulf of California, Tecolote, Cabo San Lucas and San } \\
\text { Francisquito Bay, Puerto Angelito, Puerto Escondido in Oaxaca, Guerrero } \\
\text { in the MPR No. 32, Zihuatanejo and Revillagigedo Islands) from } \\
\text { Revillagigedo Islands to northern Colombia in Gorgona Island, Costa } \\
\text { Rica in Playa de Cocos and Perú. [4,6,10-14,18-20,25,26,28,29,37] }\end{array}$ & $\begin{array}{l}\text { Punta Maldonado } 16^{\circ} 19^{\prime} 35.49^{\prime \prime} \\
98^{\circ} 34^{\prime} 12.65^{\prime \prime}\end{array}$ \\
\hline $\begin{array}{l}\text { Chaetopleura } \\
\text { (C.) } \\
\text { hanselmani }\end{array}$ & 2 items & $\begin{array}{c}\text { México; (Golfo de California, Mazatlán, Sinaloa; Estado de Guerrero en } \\
\text { la MPR No. 32; Oaxaca en Casa Mixteca, Huatulco), Colombia } \\
\text { (Jobi y Quibdo), Ecuador (Islas Galápagos) y Perú (Isla Lobos de Afuera). } \\
\text { [4,5,11,14,18,25,26,28,37] }\end{array}$ & $\begin{array}{c}\text { Salinas } 16^{\circ} 35^{\prime} 49.56^{\prime \prime} 99^{\circ} 05^{\prime} 43.71^{\prime \prime} \\
\text { Punta Maldonado } 16^{\circ} 19^{\prime} 35.49^{\prime \prime} \\
98^{\circ} 34^{\prime} 12.65^{\prime \prime}\end{array}$ \\
\hline $\begin{array}{l}\text { Tonicia }(T .) \\
\text { forbesii } \\
\text { forbesii }\end{array}$ & 1 item & $\begin{array}{l}\text { México; (Jalisco Cuastecomate Bay, Oaxaca: Chachacual-Jicaral, and } \\
\text { Estacahuite Huatulco, State of Guerrero in the MPR No. } 32 \text { and Zihuatanejo), } \\
\text { El Salvador (Punta Remedios, The Cóbano), Nicaragua, Costa Rica, Panamá } \\
\text { (Bocas del Toro), Perú and Ecuador (Galápagos Islands). [9-12,18,20,26,28,39] }\end{array}$ & $\begin{array}{c}\text { Punta Maldonado } 16^{\circ} 19^{\prime} 35.49^{\prime \prime} \\
98^{\circ} 34^{\prime} 12.65^{\prime \prime}\end{array}$ \\
\hline $\begin{array}{l}\text { Lepidochitona } \\
\text { (L.) } \\
\text { salvadorensis }\end{array}$ & 3 items & $\begin{array}{l}\text { México, (State of Guerrero in the MPR No. } 32 \text { and Oaxaca: Puerto } \\
\text { Escondido, Huatulco and Puerto Ángel), El Salvador (The Cóbanos, } \\
\text { Sonsonate and maculi Beach, La Unión). [31,14,18,26,28] }\end{array}$ & $\begin{array}{l}\text { Casa de Piedra } 16^{\circ} 32^{\prime} 10.15^{\prime \prime} \\
98^{\circ} 53^{\prime} 47.35^{\prime \prime} \\
\text { Salinas } 16^{\circ} 35^{\prime} 49.56^{\prime \prime} 99^{\circ} 05^{\prime} 43.71^{\prime \prime}\end{array}$ \\
\hline $\begin{array}{l}\text { Lepidochitona } \\
\text { (L.) } \\
\text { beanii }\end{array}$ & 5 items & $\begin{array}{l}\text { México; (Gulf of California, Santa Catalina, Puertecitos, Mazatlán, } \\
\text { State of Guerrero in the MPR No. 32), Perú (Isla Lobos de Afuera), } \\
\text { Panamá and the Caribbean. }[5,10-13,18]\end{array}$ & Salinas $16^{\circ} 35^{\prime} 49.56^{\prime \prime} 99^{\circ} 05^{\prime} 43.71^{\prime \prime}$ \\
\hline $\begin{array}{l}\text { Lepidochitona } \\
\qquad \begin{array}{l}\text { (L.) } \\
\text { hartwegii }\end{array}\end{array}$ & 2 items & $\begin{array}{l}\text { Alaska, USA also along the West Coast, North Port Orford, Oregon, Mexico, } \\
\text { (California in Sausalito, Punta Abreojos, expands distribution more } \\
\text { towards the West Coast of the Peninsula of Baja California Sur in } \\
\text { Devil 'slide and La Jolla, Rocks Stash and state of Guerrero } \\
\text { on the MPR No. 32). }[4,5,11,12,18,19,25,26]\end{array}$ & $\begin{array}{c}\text { Salinas } 16^{\circ} 35^{\prime} 49.56^{\prime \prime} 99^{\circ} 05^{\prime} 43.71^{\prime \prime} \\
\text { Punta Maldonado } 16^{\circ} 19^{\prime} 35.49^{\prime \prime} \\
98^{\circ} 34^{\prime} 12.65^{\prime \prime}\end{array}$ \\
\hline $\begin{array}{l}\text { Lepidochitona } \\
\quad \text { sp. } 1\end{array}$ & 8 items & $\begin{array}{l}\text { México, State of Guerrero in the MPR No. } 32 \text { and Oaxaca: Estacahuite). } \\
\qquad[14,18,25,26]\end{array}$ & $\begin{array}{c}\text { Salinas } 16^{\circ} 35^{\prime} 49.56^{\prime \prime} 99^{\circ} 05^{\prime} 43.71^{\prime \prime} \\
\text { Punta Maldonado } 16^{\circ} 19^{\prime} 35.49^{\prime \prime} \\
98^{\circ} 34^{\prime} 12.65^{\prime \prime}\end{array}$ \\
\hline $\begin{array}{l}\text { Lepidochitona } \\
\quad \text { sp. } 2\end{array}$ & 76 items & México, (State of Guerrero in the MPR No. 32). [18,25,26] & $\begin{array}{l}\text { Playa Ventura } 16^{\circ} 32^{\prime} 8.3^{\prime \prime} 99^{\circ} 54^{\prime} 44.6^{\prime \prime} \\
\text { Punta Maldonado } 16^{\circ} 19^{\prime} 35.49^{\prime \prime} \\
98^{\circ} 34^{\prime} 12.65^{\prime \prime}\end{array}$ \\
\hline
\end{tabular}




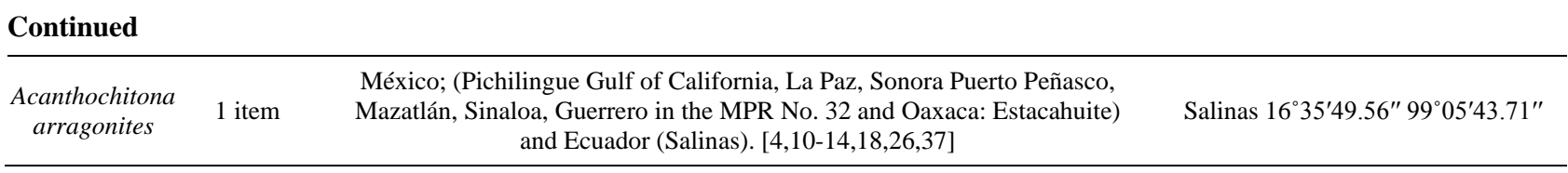

\subsection{Density}

References [18,20,21] reported Chiton (C.) articulatus as the most abundant species. $[27,28]$ reported Chiton $(C$.) albolineatus with higher density. [17,23-25] reported Ischnochiton (I.) muscarius, Callistoplax retusa, Chaetopleura (C.) lurida, Chiton (C.) albolineatus and Chiton (C.) articulatus as those with highest density.

This work coincides with the aforementioned authors, that Chiton (C.) articulatus, Ischnochiton (I.) muscarius and Chiton (C.) albolineatus are those with highest population density and therefore were considered to be the POLYPLACOPHORA species representing intertidal rocky substrate at MPR 33.

\subsection{Body Measurements}

There was greater information available on the size structure of Chiton (C.) articulatus than any other species, since it is commercially important as mentioned by [14,22]; as is Chiton (C.) albolineatus in Mazatlan and the southwestern region on the Gulf of California stated by [16]. Regarding size structure for other species [15] reported that found no biometric information was found other than for Chiton (C.) articulatus, except for some data on size and referred to as total length. Few reports were found in the community about size structure. Reference $[23,25]$ reported Chiton (C.) articulatus and Tonicia (T.) forbesii forbesii as the species with larger size. This study is consistent with earlier reports on the above mentioned parameters. These relationships allow biometric estimation for any individual for its condition factor and growth rate, and to estimate different coefficients which can then be compared with other's measurements in further analysis.

\subsection{Diversity Index}

Reference [23,24] reported high diversity indices for Acapulco high diversity indices similar to those estimated in the present study. The diversity index and the equality' that is reported in this paper indicate that the MPR 33 is a highly diverse area, finding species richness and abundance as expected for a tropical area.

\subsection{Geography Distribution}

Reference [4] reported 23 species of POLYPLACOPHORA distributed in the Tropical Pacific coasts, from the species they reported: Ischnochiton (I.) muscarius, Stenoplax (S.) limaciformis, Callistoplax retusa, Chae- topleura (C.) lurida, Chaetopleura (C.) hanselmani, Chiton (C.) articulatus, Chiton (C.) albolineatus, Tonicia (T.) forbesii forbesii and Lepidochitona (L.) beanii were found in the MPR 33.

Reference [11] in a study of Chitons in Mexican waters updated the species distribution including species endemic to the Eastern Pacific, with a total of 57 species of which: Ischnochiton (I.) muscarius, Stenoplax (S.) butterfly, Stenoplax (S.) limaciformis, Lepidozona (L.) serrata, Callistoplax retusa, Chiton (C.) articulatus, Chiton (C.) albolineatus and Acanthochitona arragonites are reported for here for the MPR 33.

Reference [17] for the MPR No. 32 reported Ischnochiton (I.) muscarius, Chiton (C.) albolineatus and Chiton (C.) articulatus as widespread species. [26] reported the Chiton (C.) articulatus as widely distributed on the coast of the State of Guerrero since he found them in nine beaches in the three coastal regions. Our work also found Chiton (C.) articulatus and Stenoplax (S.) limaciformis to be widespread species. Therefore both species are considered representative of the rocky intertidal MPR 33.

Reference [17] reported four species with irregular distribution. In the present investigation nine species were identified with this type of distribution coinciding with the aforementioned report in: Stenoplax (S.) mariposa, Callistoplax retusa and Lepidochitona (L.) hartwegii The differences in the geographical distribution of species by comparing the MPR 32 and 33 could be due mainly to less variety in structure of the substrate, wave exposure and stability for rocky intertidal sites sampled in MPR 33.

\section{ACKNOWLEDGEMENTS}

This work was partly funded by CONACYT (Consejo Nacional de Ciencia y Tecnologia-National Council for Science and Technology) and the State Government of Guerrero through the research project No. 91.724 Diversity, abundance and development of the marine cockroach in the coast of the State Guerrero, Mexico.

\section{REFERENCES}

[1] Wilkinson, T., Wiken, E., Bezaury Creel, J., Hourigan, T., Agardy, T., Herrmann, H., Janishevski, L., Madden, C., Morgan, L. and Padilla, M. (2009) Ecorregiones marinas de américa del norte. Comisión para la Cooperativa Ambiental, Montreal.

[2] Arriaga, L., Vázquez, E., González, J., Jiménez, R., Muñoz, E., et al. (1998) Regiones prioritarias marinas de 
México. Comisión Nacional para el Conocimiento y Uso de la Biodiversidad, México.

[3] Reyes, G.A. (1999) Sistemática de los quitones (Mollusca: Polyplacophora) de la Colección de Moluscos del Instituto de Biología de UNAM. Tesis de Licenciatura, Universidad Nacional Autónoma de México, México.

[4] Reyes-Gómez, A. and Salcedo-Vargas, M.A. (2002) The recent Mexican chiton (Mollusca: Polyplacophora) Species. The Festivus, 34, 17-27.

[5] Kaas, P. and Van Belle, R.A. (1985) Monograph of Living Chitons-Mollusca-Polyplacophora: Volume 2. Suborder Ischnochitonina-Ischnochitonidae-Schizoplacinae, Callochitoninae and Lepidochitoninae. E. J. Brill/W. Backhuys, Leiden.

[6] Kaas, P. and Van Belle, R.A. (1987).Monograph of Living Chitons (Mollusca: Polyplacophora). Volume 3. Suborder Ischnochitonina Ischnochitonidae: Chaetopleurinae, \& Ischnochitoninae (Pars) Additions to Vols 1 \& 2. E. J. Brill/Dr. W. Backhuys, Leiden, New York, Koln, Kobenhavn.

[7] Kaas, P. and Van Belle, R.A. (1990) Monograph of Living Chitons (Mollusca: Polyplacophora). Vol. 4. Suborder Ischnochitonina: Ischnochitonidae: Ischnochitoninae (cont.). Addition to vols. 1, 2 and 3. E. J. Brill/W. Backhuys, Leiden.

[8] Kaas, P. and Van Belle, R.A. (1994) Monograph of Living Chitons (Mollusca: Polyplacophora). Vol. 5. Suborder Ischnochitonina: Ischnochitonidae: Ischnochitoninae (concluded); Callistoplacinae; Mopaliidae. Addition to Vols. 1-4. E. J. Brill/W. Backhuys, Leiden.

[9] Kaas, P., Van Belle, A.R. and Strack, L.H. (2006) Monograph of Living Chitons (Mollusca: Polyplacophora): Volumen 6, Family Schizochitonidae. E. J. Brill/W. Backhuys, Leiden.

[10] Keen, A.M. (1971) Sea shells of tropical West America. Stanford University Press, California.

[11] Skoglund, C. (2001) Panamic province molluscan literature additions and changes from 1971 through 2000. I. Bivalvia and II Polyplacophora. The Festivus, 32, 39.

[12] Reyes-Gómez A. (2004) Chitons in Mexican waters. Bollettino Malacologico, 5, 69-82.

[13] García C.I. and Álvarez M. (2007) Comunidades de quitones (Mollusca: Polyplacophora) de la Bahía de la Paz California Sur, México. Revista de Biología Tropical, 55, 177-82.

[14] Reyes-Gómez, N., Barrientos-Lujan, N., Medina-Bautista, J. and Ramírez-Luna, S. (2010) Chitons from the coralline area of Oaxaca, Mexico (Polyplacophora). Bollettino Malacologico, 46, 111-125.

[15] Holguín, Q.O.E. and Michel-Morfín, J. E. (2002) Distribution, density and length-weight relationship of Chiton articulatus Sowerby, 1832 (Mollusca-Polyplacophora) on Isla Socorro, Revillagigedo Archipelago, Mexico. Journal of Shellfish Research, 21, 239-241.

[16] Flores-Campaña, L.M., González-Montoya, M.A., OrtizArellano, M.A. and Arzola-González, J.F. (2007) Estructura de Chiton articulatus en las islas Pájaros y Venados de la bahía de Mazatlán, Sinaloa, México.
Revista Mexicana de Biodiversidad, 78, 23-71.

[17] Flores-Campaña, L.M., Arzola-González, J.F. and LeónHerrera, R. (2012) Body size structure, biometric relationships and density of Chiton albolineatus (Mollusca: Polyplacophora) on the intertidal rocky zone of three islands of Mazatlan Bay, SE of the Gulf of California. Revista de Biología Marina Oceanografía, 47, 203-211. http://dx.doi.org/10.4067/S0718-19572012000200004

[18] Flores-Garza, R., Galeana-Rebolledo, L., Reyes-Gómez, A., García-Ibáñez, S., Torreblanca-Ramírez, C., FloresRodríguez P. and Valdés G.A. (2012) Polyplacophora species richness, composition and distribution of its community associated with the intertidal rock substrate in the marine priority region No. 32 in Guerrero, Mexico. Open Journal of Ecology, 2, 192-201. http://dx.doi.org/10.4236/oje.2012.24023

[19] Villalpando, C.E. (1986) Diversidad y zonación de moluscos de superficie rocosa, Isla Roqueta, Acapulco, Guerrero. Tesis de Licenciatura, Universidad Nacional Autónoma de México, México.

[20] Salcedo, S., Green, G., Gamboa, A. and Gómez, P. (1988) Inventario de macroalgas y macroinvertebrados bénticos, presentes en áreas rocosas de la región de Zihuatanejo, Guerrero, México. Anales del Instituto de Ciencias del Mar y Limnología Universidad Nacional Autónoma de México, 15, 73-96.

[21] García, J.A. (1994) Fauna malacológica de acompañamiento del caracol Purpura pansa (Gould, 1853) en la zona mesolitoral de la isla Roqueta, Acapulco, Guerrero, México. Tesis de Licenciatura, Universidad Autónoma de Guerrero, Acapulco.

[22] Flores, R.P. (2004) Estructura de la comunidad de moluscos del mesolitoral superior en las playas de facie rocosa del estado de Guerrero, México. Tesis doctoral, Universidad Autónoma de Nuevo León, San Nicolás de los Garza.

[23] Flores-Garza, R., Flores-Rodríguez, P., García-Ibáñez S. and Valdés-González, A. (2007) Demografía del caracol Plicopurpura pansa (Neotaenioglossa: Muricidae) y constitución de la comunidad malacológica asociada en Guerrero, México. Revista de Biología Tropical, 55, 867887.

[24] Torreblanca, R.C. (2010). Análisis de la diversidad y estructura de la comunidad de moluscos del mesolitoral rocoso de Acapulco, Gro. Tesis de Licenciatura, Unidad Académica de Ecología Marina, Universidad Autónoma de Guerrero, Acapulco, Guerrero.

[25] Flores-Garza, R., Galeana-Rebolledo, L., García-Ibáñez, S., Flores-Rodríguez P. and Torreblanca-Ramírez, C. (2010) Diversidad y estructura de la comunidad de Polyplacophora en el mesolitoral rocoso, Acapulco, Guerrero, México. In: Rangel, R.L.J., Gamboa, A.J., Arriaga, W.S. and Contreras, S.W.M., Eds, Perspectiva en Malacología Mexicana, Universidad Juárez Autónoma de Tabasco, Tabasco, México, 141-152.

[26] Flores-Garza, R., Torreblanca-Ramírez, C., Flores- Rodríguez, P., García-Ibáñez, S., Galeana-Rebolledo, L., Valdés-González A. and Rojas-Herrera, A.A. (2011) Mollusca community from a rocky intertidal zone in Acapulco, México. Biodiversity, 12, 144-153. 
http://dx.doi.org/10.1080/14888386.2011.625520

[27] Flores-Rodríguez, P., Flores-Garza, R., García-Ibáñez, S., Valdés-González, A., Violante-González, J., Santiago, C.E., Galeana-Rebolledo, L. and Torreblanca-Ramírez, C. (2012) Mollusk species richness on the rocky shores of the State of Guerrero, Mexico, as affected by rains and their geographical distribution. Natural Resources, 3, 248-260. http://dx.doi.org/10.4236/nr.2012.34032

[28] Torreblanca-Ramírez, C., Flores-Garza, R., FloresRodríguez, P., García-Ibáñez, S. and Galeana-Rebolledo, L. (2012) Riqueza, composición y diversidad de la comunidad de moluscos asociada al sustrato rocoso intermareal de playa Parque de la Reina, Acapulco, Guerrero, México. Revista de Biología Marina y Oceanografía, 47, 283-294. http://dx.doi.org/10.4067/S0718-19572012000200010

[29] Galeana-Rebolledo, L., Flores-Garza, R., TorreblancaRamírez, C., García-Ibáñez, S., Flores-Rodríguez, P. and López-Rojas, V.I. (2012) Biocenosis de Bivalvia y Polyplacophora del intermareal rocoso en playa Tlacopanocha, Acapulco, Guerrero, México. Latín American Journal of Aquatic Research, 40, 943-954. http://dx.doi.org/10.3856/vol40-issue4-fulltext-11

[30] Mottana, A., Crespi, R. and Liborio, G. (1980) Guía de minerales y rocas, segunda edición, Grijalbo, Barcelona.

[31] García-Ríos, C.I. (2006) A New Species of Lepidochitona
(Mollusca: Polyplacophora) from El Salvador. The Veliger, 48, 206-214.

[32] Sirenko, B. (2006) New outlook on the system of Chitons (Mollusca: Polyplacophora). Venus, 65, 27-49.

[33] Sokal, R.R. and Rohlf, F.J. (1969) Biometry. The principles and practices of statistics in biological research. 2nd Edition, W.H. Freeman, San Francisco.

[34] Brusca, R.R. (1980) Common intertidial invertebrates of the Gulf of California. The University of Arizona Press, Tucson.

[35] Spight, T.M. (1976) Censuses of rocky shore prosobranchs from Washington and Costa Rica. The Veliger, 18, 309-317.

[36] Martinez-Morales, M.A. (2004) Nuevos registros de aves en el bosque de mesófilo de montaña del noreste de Hidalgo, México. Huitzil, 5, 12-19.

[37] World Register of Marine Species, 2013. http://www.marinespecies.org/

[38] Global Species, 2013. http://www.globalspecies.org/

[39] Wmsdb-worldwide mollusc species data base, 2013. http://unsw.discoverlife.org/mp/20q?guide=Mollusca_Pol yplacophora_species\&flags=HAS 